J. Dairy Sci. 95:7336-7339

http://dx.doi.org/10.3168/jds.2012-5881

(C) American Dairy Science Association ${ }^{\circledR}, 2012$.

\title{
Short communication: Glutamine increases autophagy of liver cells in weaned calves
}

\author{
Z. Y. Hu, S. L. Li, ${ }^{1}$ and Z. J. Cao ${ }^{1}$ \\ State Key Laboratory of Animal Nutrition, College of Animal Science and Technology, China Agricultural University, Beijing, China, 100193
}

\begin{abstract}
The objectives of this study were to determine the effects of an increased jugular supply of L-Gln on the autophagy of weaned calves. At $35 \mathrm{~d}$ of age, 24 Holstein calves (initial body weight of $50 \pm 0.5 \mathrm{~kg}$; $35 \pm 2 \mathrm{~d}$ of age) were randomly allocated to 4 treatments, with each treatment including 5 male calves and 1 female calf. Holstein calves were assigned to treatments of (1) intravenous infusion of $2 \mathrm{~L}$ of $0.85 \% \mathrm{NaCl}$ (control group) (2) intravenous infusion of $8 \mathrm{~g} / \mathrm{d}$ of L-Gln mixed with $2 \mathrm{~L}$ of $0.85 \% \mathrm{NaCl}$ solution, (3) intravenous infusion of $16 \mathrm{~g} / \mathrm{d}$ of L-Gln mixed with $2 \mathrm{~L}$ of $0.85 \% \mathrm{NaCl}$ solution, and (4) intravenous infusion of $32 \mathrm{~g} / \mathrm{d}$ of LGln mixed with $2 \mathrm{~L}$ of $0.85 \% \mathrm{NaCl}$. The infusion was administered $2 \mathrm{~h} / \mathrm{d}$ for 7 consecutive days starting on d 1 after weaning. Feed and water were freely available to all calves. All calves were killed on d 7 postweaning to measure the autophagy of liver cells. The level of autophagy in liver cells was improved when the Gln infusion dose increased.
\end{abstract}

Key words: calf, glutamine, autophagy

\section{Short Communication}

Weaning, the transition from the ingestion of maternal milk to solid foods, is a particularly vulnerable period for mammals, with increased incidences of malnutrition, intestinal infections, and poor growth (Blecha et al., 1983; Wilson et al., 1989; Spreeuwenberg et al., 2001). During periods of physiological stress, such as trauma, burns, and postoperative recovery, supplemental Gln has proved beneficial (Lacey and Wilmore, 1990). Some of the stress protection exerted by Gln is thought to be due to the stimulation of autophagy in intestinal cells (Nakagawa et al., 2004; Sakiyama et al., 2009). Autophagy is the lysosome-dependent degradation of cellular proteins that is induced when cells are exposed to stresses such as a nutrient limitation, heat, oxidative challenge, and an accumulation of damaged

\footnotetext{
Received June 27, 2012.

Accepted July 23, 2012.

${ }^{1}$ Corresponding authors: lisheng0677@163.com and caozhijun@cau. edu.cn
}

or excess organelles and abnormal cellular components (Yorimitsu and Klionsky, 2005). The elimination of potentially toxic components coupled with the recycling of nutrients aids in cell survival (Levine and Klionsky, 2004). Two mechanisms have been proposed for the stimulatory effect of Gln on autophagy in various cell types. One involves inhibition of the autophagysuppressing kinase, mammalian target of rapamycin (mTOR; Nakajo et al., 2005; Sakiyama et al., 2009), whereas the other involves the mTOR-independent stimulation of autophagy by $\mathrm{NH}_{3}$ liberated during glutaminolysis (Cheong et al., 2011). Intravenous infusion of Gln in calves increased intestinal glutaminolysis and $\mathrm{NH}_{3}$ release into the portal vein feeding the liver (Nappert et al., 1999). Whether Gln or $\mathrm{NH}_{3}$ stimulates autophagy in the liver remains unknown. The purpose of our study was to evaluate the effect of Gln on the autophagy of liver in weaned calves.

Animal care and use were approved and conducted under established standards of the College of Animal Science and Technology, China Agricultural University,

Table 1. Ingredient and nutrient composition of the experimental starter

\begin{tabular}{lc}
\hline Item & Content \\
\hline Ingredient, \% of DM & \\
Corn grain & 47 \\
Wheat bran & 13 \\
Soybean meal & 20 \\
Extruded soybeans & 8.4 \\
Corn gluten meal & 7 \\
Salt & 0.55 \\
CaCO ${ }_{3}$ & 2.1 \\
Dicalcium phosphate & 1.15 \\
Vitamin and trace mineral premix ${ }^{1}$ & 0.8 \\
Nutrient, \% of DM & 90.1 \\
DM, \% & 21.25 \\
CP & 4.29 \\
Crude fat & 16.75 \\
NDF & 6.82 \\
ADF & 1.07 \\
Ca & 0.56 \\
P & 2.81 \\
ME ${ }^{2}$ Mcal/kg & \\
${ }^{1}$ Premix contained $(\mathrm{mg} / \mathrm{kg}):$ vitamin A, 4,035; vitamin $\mathrm{D}, 1,740 ;$ vi- \\
tamin E, 39; Fe, 18; Zn, 37; Cu, 10.6; Mn, 15.3; Co, 0.12; I, $0.47 ;$ and \\
Se, 0.35. \\
${ }^{2}$ Calculated following NRC (2001) recommendations.
\end{tabular}


Table 2. Effects of Gln infusion on the number of autophagosomes in liver cells ${ }^{1}$

\begin{tabular}{|c|c|c|c|c|c|c|c|}
\hline \multirow[b]{2}{*}{ Item } & \multicolumn{4}{|c|}{ Gln, dose g/d } & \multicolumn{3}{|c|}{ Effect } \\
\hline & 0 & 8 & 16 & 32 & $\mathrm{RMSE}^{2}$ & Linear & Quadratic \\
\hline Autophagosome, no./cell & 0.5 & 1.5 & 2.1 & 2.5 & 0.25 & $<0.01$ & $<0.01$ \\
\hline \multicolumn{8}{|c|}{$\begin{array}{l}{ }^{1} \text { Treatments were as follows: (1) intravenous infusion of } 2 \mathrm{~L} \text { of } 0.85 \% \mathrm{NaCl} \text { (control group), (2) intravenous } \\
\text { infusion of } 8 \mathrm{~g} / \mathrm{d} \text { of } \mathrm{L}-\mathrm{Gln} \text { mixed with } 2 \mathrm{~L} \text { of } 0.85 \% \mathrm{NaCl} \text { solution ( } \mathrm{L} \text { group), (3) intravenous infusion of } 16 \mathrm{~g} / \mathrm{d} \\
\text { of } \mathrm{L}-\mathrm{Gln} \text { mixed with } 2 \mathrm{~L} \text { of } 0.85 \% \mathrm{NaCl} \text { solution (M group), (4) intravenous infusion of } 32 \mathrm{~g} / \mathrm{d} \text { of } \mathrm{L}-\mathrm{Gln} \text { mixed } \\
\text { with } 2 \mathrm{~L} \text { of } 0.85 \% \mathrm{NaCl} \text { (H group). }\end{array}$} \\
\hline
\end{tabular}

Beijing, China. Calves were randomly assigned to treatments by date of birth and were housed individually in $1.5 \times 3.4 \mathrm{~m}$ pens inside a naturally ventilated barn. All calves received $4 \mathrm{~L}$ of colostrum initially, and then were fed $4 \mathrm{~L}$ of whole milk once daily until weaning. Fresh calf starter (Table 1) was offered ad libitum beginning at $3 \mathrm{~d}$ of age. Water was offered free-choice daily. Calves were weaned at $5 \mathrm{wk}$.

Between 35 and $42 \mathrm{~d}$ of age, 24 calves were infused daily from 0800 to $1000 \mathrm{~h}$ with $2 \mathrm{~L}$ of $0.85 \% \mathrm{NaCl}$ con-
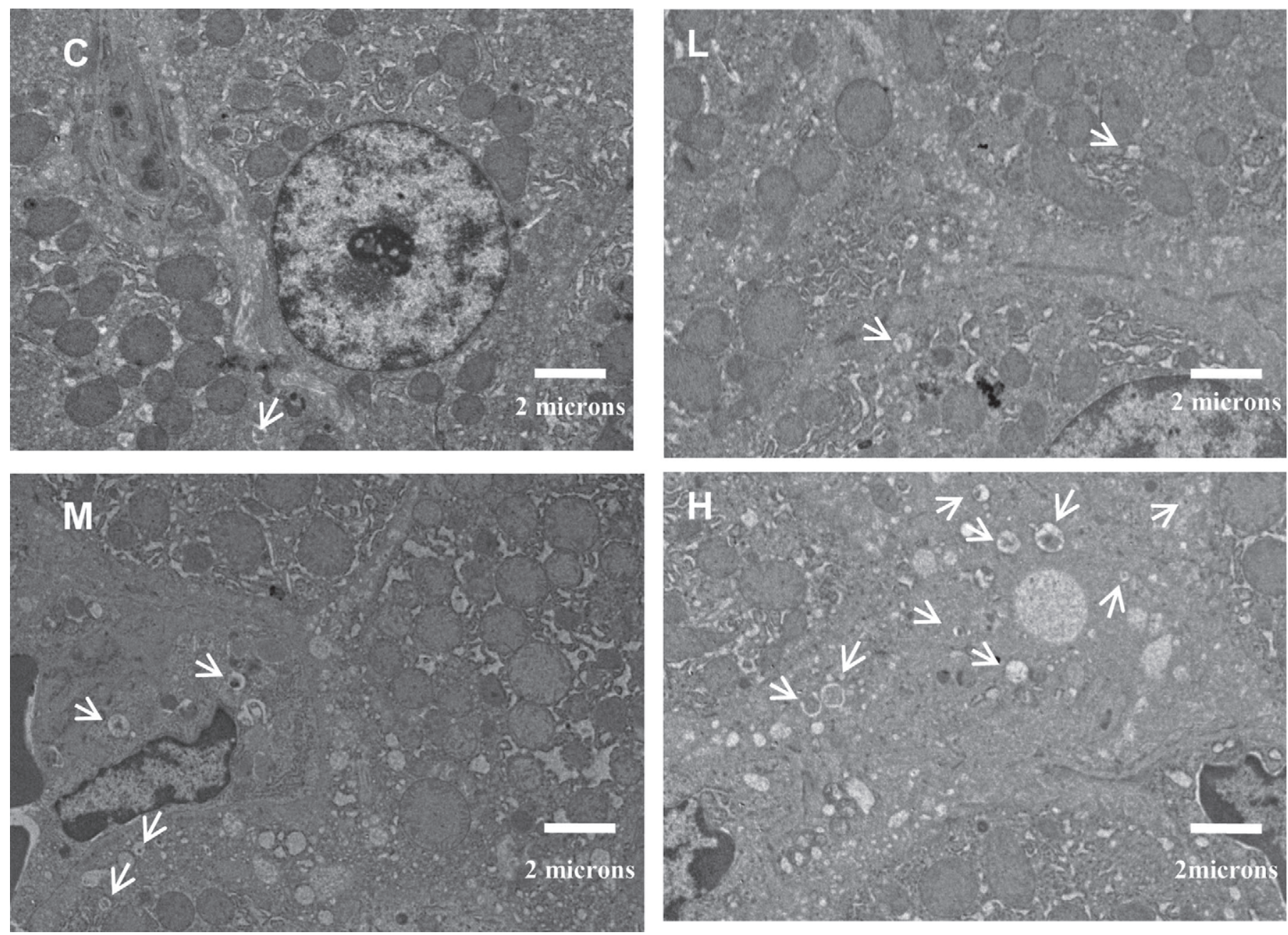

Figure 1. Effects of Gln infusion on the autophagy of liver cells. Treatments were as follows: (1) intravenous infusion of $2 \mathrm{~L}$ of $0.85 \% \mathrm{NaCl}$ [control (C) group]; 2) intravenous infusion of $8 \mathrm{~g} / \mathrm{d}$ of L-Gln mixed with $2 \mathrm{~L}$ of $0.85 \% \mathrm{NaCl}$ solution (L group); (3) intravenous infusion of 16 $\mathrm{g} / \mathrm{d}$ of L-Gln mixed with $2 \mathrm{~L}$ of $0.85 \% \mathrm{NaCl}$ solution (M group); 4) intravenous infusion of $32 \mathrm{~g} / \mathrm{d}$ of $\mathrm{L}-\mathrm{Gln}$ mixed with $2 \mathrm{~L}$ of $0.85 \% \mathrm{NaCl}$ ( $\mathrm{H}$ group). Arrows indicate autophagosomes. 
taining 0 (control group), 8, 16, and $32 \mathrm{~g} / \mathrm{d}$ of L-Gln. L-Glutamine was dissolved in $2 \mathrm{~L}$ of isotonic $(0.85 \%)$ $\mathrm{NaCl}$ in double-distilled and pyrogen-free water, filtersterilized through a $0.22-\mu \mathrm{m}$ membrane, and then stored in sterile containers. Solutions were prepared once every $3 \mathrm{~d}$ and kept refrigerated before use. Calves were equipped with indwelling jugular venous catheters on the first day of infusion. When not in use, the catheters were filled with $0.85 \%$ sterile saline containing $5,000 \mathrm{U} /$ $\mathrm{mL}$ of heparin (Sigma-Aldrich Ltd., Shanghai, China) to prevent clot formation.

All calves were killed at $42 \mathrm{~d}$ of age. After opening the body cavity, a sample of liver was fixed with $2.5 \%$ glutaraldehyde in $100 \mathrm{~m} M$ PBS buffer for $12 \mathrm{~h}$. After washing, the sample was postfixed with $1 \% \mathrm{OsO}_{4}$ at room temperature, dehydrated in a graded series of alcohol, and embedded in Epon 812 resin (Fluka, Buchs, Switzerland). Seventy-nanometer sections were prepared on an ultramicrotome (EM UC6, Leica, Solms, Germany) with a diamond knife, picked up on Formvar-coated grids, stained with uranyl acetate and lead citrate, and viewed under an electron microscope (H-7650, Hitachi, Tokyo, Japan). Autophagosomes were counted in 50 cells per section.

Another sample of liver was stored at $-80^{\circ} \mathrm{C}$ until analyzed for microtubule-associated protein 1 light chain 3 (LC3) as a marker of autophagy. Frozen samples were homogenized, and proteins were separated by $15 \%$ SDSPAGE and transferred to a polyvinylidene difluoride membrane with the Trans-Blot SD System (Bio-Rad Laboratories, Hercules, CA). Membranes were blocked with BSA and incubated overnight at $4^{\circ} \mathrm{C}$ with antiLC3 (Zhongyuan Ltd., Beijing, China) and anti-actin antibodies (Sigma-Aldrich Ltd.). Membranes were then probed with secondary antibody and detected using SuperSignal West Dura Chemiluminescent Substrate (Thermo Fisher Scientific Ltd., Shanghai, China). The band density was quantified with ImageJ software (National Institutes of Health, Bethesda, MD).

All data were analyzed as a completely randomized design using PROC GLM of SAS 9.0 (SAS Institute Inc., Cary, NC). Orthogonal polynomial contrasts were computed for linear and quadratic effects of dose. Significance was declared at $P<0.05$.

To investigate whether infusion Gln would have effects on autophagy, the number of autophagosomes in the liver was examined by electronic microscopy. We found that infusion of Gln increased the level of autophagy in liver cells. The number of autophagosomes in the liver cells increased linearly $(P<0.01)$ with an increase in Gln infusion (Figure 1 and Table 2). From the Western blot result, we found that the abundance of LC3 increased linearly $(P<0.05)$ as the Gln infusion dose increased (Figure 2)
Autophagy was originally described as a cellular response to starvation (Nakatogawa et al., 2009). Later, autophagic induction was found to play critical roles in various cellular responses, such as prevention of infection by bacteria and viruses (Nakagawa et al., 2004; Orvedahl and Levine, 2009), early embryogenesis (Tsukamoto et al., 2008), antigen presentation (Paludan et al., 2005; English et al., 2009), neural development (Fimia et al., 2007), survival of newborns (Kuma et al., 2004), and lipid metabolism (Singh et al., 2009). Sakiyama et al. (2009) reported that Gln can induce autophagy under basal and stressed conditions. Deldicque et al. (2008) also reported that Gln has antagonistic effects on the mTOR pathway in myogenic $\mathrm{C} 2 \mathrm{C} 12$ cells. Mammalian target of rapamycin is involved in the negative control of autophagy and has been proposed as a nutrient sensor (Kadowaki et al., 2006). Likewise, Häussinger et al. (1999) found that p38 mitogen-activated protein (MAP) kinase had a negative effect on the regulation of autophagy in hepatocytes. Comes et al. (2007) reported that Gln can induce autophagy by inhibiting the p38 MAP kinase pathway in colorectal cancer cells.

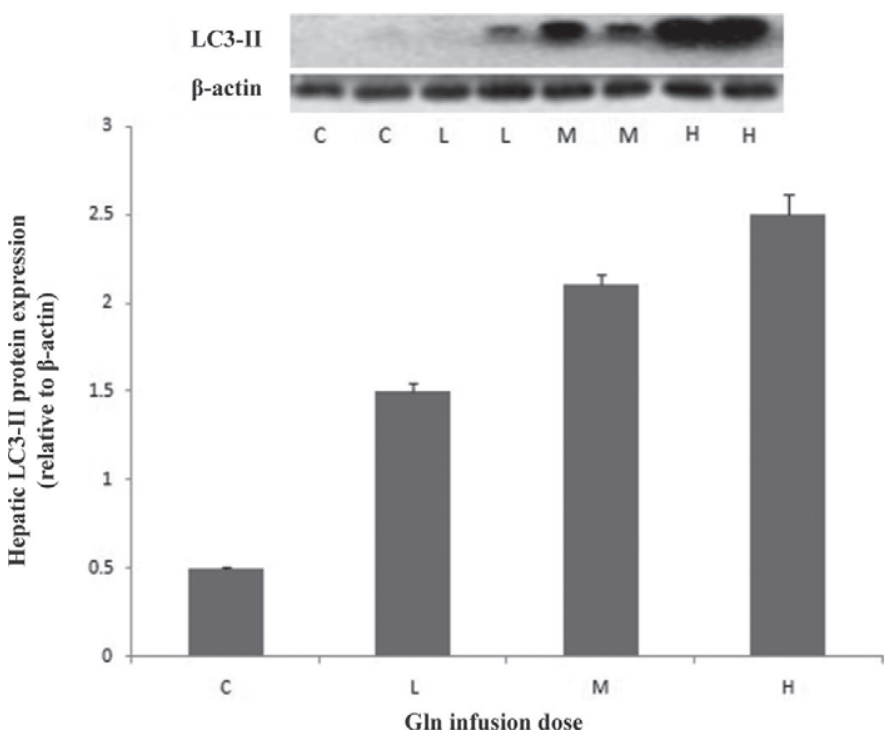

Figure 2. Effects of Gln infusion on the autophagy of liver cells. Levels of microtubule-associated protein 1 light chain 3-II (LC3-II) protein as assessed by Western blot analysis. Treatments were as follows: (1) intravenous infusion of $2 \mathrm{~L}$ of $0.85 \% \mathrm{NaCl}$ [control group (C)]; (2) intravenous infusion of $8 \mathrm{~g} / \mathrm{d}$ of L-Gln mixed with $2 \mathrm{~L}$ of $0.85 \% \mathrm{NaCl}$ solution (L group); (3) intravenous infusion of $16 \mathrm{~g} / \mathrm{d}$ of L-Gln mixed with $2 \mathrm{~L}$ of $0.85 \% \mathrm{NaCl}$ solution (M group); (4) intravenous infusion of $32 \mathrm{~g} / \mathrm{d}$ of L-Gln mixed with $2 \mathrm{~L}$ of $0.85 \% \mathrm{NaCl}(\mathrm{H}$ group). Hepatic LC3-II protein expression in response to Gln infusion in calves. Insets depict representative blots. Values represent means $t$ SE. Response from linear statistical result, $P<0.05$. $\beta$-Actin was used to normalize the expression of target proteins. 
In this experiment, we found that Gln induced autophagy in liver cells, and that the autophagy levels increased linearly as the Gln infusion dose increased. The reason may be that Gln reverses the activity of p70S6 kinase, a downstream target of mTOR, and inhibits p38 MAP kinase activity or mTOR-independent stimulation of autophagy by $\mathrm{NH}_{3}$ liberated during glutaminolysis.

In conclusion, an exogenous supply of Gln increased the level of autophagy in the liver cells of weaned calves. To the authors' knowledge, this is the first study to report the effects of Gln on the autophagy of liver cells in the calf.

\section{ACKNOWLEDGMENTS}

The author gratefully thank the staff of the Hailin Dairy Farm of Tianjin, China.

\section{REFERENCES}

Blecha, F., D. S. Pollmann, and D. A. Nichols. 1983. Weaning pigs at an early age decreases cellular immunity. J. Anim. Sci. 56:396400.

Cheong, H., T. Lindsten, J. Wu, C. Lu, and C. B. Thompson. 2011. Ammonia-induced autophagy is independent of ULK1/ULK2 kinases. Proc. Natl. Acad. Sci. USA 108:11121-11126.

Comes, F., A. Matrone, and P. Lastella. 2007. A novel cell type-specific role of $\mathrm{p} 38 \alpha$ in the control of autophagy and cell death in colorectal cancer cells. Cell Death Differ. 14:693-702.

Deldicque, L., C. Sanchez Canedo, and S. Horman. 2008. Antagonistic effects of leucine and glutamine on the mTOR pathway in myogenic $\mathrm{C}_{2} \mathrm{C}_{12}$ cells. Amino Acids 35:147-155.

English, L., M. Chemali, J. Duron, C. Rondeau, A. Laplante, D. Gingras, D. Alexander, D. Leib, C. Norbury, R. Lippe, and M. Desjardins. 2009. Autophagy enhances the presentation of endogenous viral antigens on MHC class I molecules during HSV-1 infection. Nat. Immunol. 10:480-487.

Fimia, G. M., A. Stoykova, A. Romagnoli, L. Di. Giunta, S. Bartolomeo, R. Nardacci, M. Corazzari, C. Fuoco, A. Ucar, and P. Schwartz. 2007. Ambra1 regulates autophagy and development of the nervous system. Nature 447:1121-1125.

Häussinger, D., F. Schliess, and F. Dombrowski. 1999. Involvement of p38MAPK in the regulation of proteolysis by liver cell hydration. Gastroenterology 116:921-935.

Kadowaki, M., M. R. Karim, and A. Carpi. 2006. Nutrient control of macroautophagy in mammalian cells. Mol. Aspects Med. 27:426443.
Kuma, A., M. Hatano, M. Matsui, A. Yamamoto, H. Nakaya, T. Yoshimori, Y. Ohsumi, T. Tokuhisa, and N. Mizushima. 2004. The role of autophagy during the early neonatal starvation period. Nature 432:1032-1036.

Lacey, J. M., and D. W. Wilmore. 1990. Is glutamine a conditionally essential amino acid? Nutr. Rev. 48:297-309.

Levine, B., and D. J. Klionsky. 2004. Development by self-digestion: Molecular mechanisms and biological functions of autophagy. Dev. Cell 6:463-477.

Nakagawa, I., A. Amano, N. Mizushima, A. Yamamoto, H. Yamaguchi, T. Kamimoto, A. Nara, J. Funao, M. Nakata, K. Tsuda, S. Hamada, and T. Yoshimori. 2004. Autophagy defends cells against invading group A Streptococcus. Science 306:1037-1040.

Nakajo, T., T. Yamatsuji, H. Ban, K. Shigemitsu, M. Haisa, T. Motoki, and K. Noma. 2005. Glutamine is a key regulator for amino acid-controlled cell growth through the mTOR signaling pathway in rat intestinal epithelial cells. Biochem. Biophys. Res. Commun. 326:174-180.

Nakatogawa, H., K. Suzuki, Y. Kamada, and Y. Ohsumi. 2009. Dynamics and diversity in molecular mechanisms of autophagy: Lessons from yeast studies. Nat. Rev. Mol. Cell Biol. 10:458-467.

Nappert, G., G. A. Zello, J. Ferguson, and J. M. Naylor. 1999. Examination of metabolism of viscera drained by the portal vein in neonatal calves, using short-term intravenous infusions of glutamine and other nutrients. Am. J. Vet. Res. 60:437-445.

NRC. 2001. Nutrient Requirements of Dairy Cattle. 7th rev. ed. Natl. Acad. Sci., Washington, DC.

Orvedahl, A., and B. Levine. 2009. Autophagy in mammalian antiviral immunity. Curr. Top. Microbiol. Immunol. 335:267-285.

Paludan, C., D. Schmid, M. Landthaler, M. Vockerodt, D. Kube, T. Tuschl, and C. Munz. 2005. Endogenous MHC class II processing of a viral nuclear antigen after autophagy. Science 307:593-596.

Sakiyama, T., M. W. Musch, M. J. Ropeleski, H. Tsubouchi, and E. B. Chang. 2009. Glutamine increases autophagy under basal and stressed conditions in intestinal epithelial cells. Gastroenterology 136:924-932.

Singh, R., S. Kaushik, Y. Wang, Y. Xiang, I. Novak, M. Komatsu, K. Tanaka, A. M. Cuervo, and M. J. Czaja. 2009. Autophagy regulates lipid metabolism. Nature 458:1131-1135.

Spreeuwenberg, M. A. M., J. M. A. J. Verdonk, H. R. Gaskins, and M. W. A. Verstegen. 2001. Small intestine epithelial barrier function is compromised in pigs with low feed intake at weaning. J. Nutr. 131:1520-1527.

Tsukamoto, S., A. Kuma, M. Murakami, C. Kishi, A. Yamamoto, and N. Mizushima. 2008. Autophagy is essential for preimplantation development of mouse embryos. Science 321:117-120.

Wilson, A. D., C. R. Stokes, and J. Bourne. 1989. Effect of age on absorption and immune response to weaning or introduction of novel dietary antigens in pigs. Res. Vet. Sci. 46:180-186.

Yorimitsu, T., and D. J. Klionsky. 2005. Autophagy: Molecular machinery for self-eating. Cell Death Differ. 12(Suppl. 2):1542-1552. 